\title{
GOVERNMENT ROLES IN PUBLIC-PRIVATE PARTNERSHIPS PROCUREMENT OF INFRASTRUCTURES: THEORETICAL APPROACH
}

\author{
RAPHEAL ABIODUN OJELABI, OLABOSIPO ISHOLA FAGBENLE, LEKAN MURITALA \\ AMUSAN, and ADEDEJI OLUSHOLA AFOLABI \\ Dept of Building Technology, Covenant University, Ota, Nigeria
}

\begin{abstract}
Social and economic infrastructures provision has been the sole responsibility of the government in the time past. However, due to the geometric demand in human infrastructures needs, the government supply capacity has been constrained. The inability of the government to close the infrastructural gaps is due to the inequality in financial capacity and the financial worth of social and economic infrastructures. Despite the paucity of the fund required for infrastructures provisions in government, the need for social and economic infrastructures cannot wait due to its relevance in nation-building. The innovative approach to meeting the social and economic infrastructures is engineered through the adoption of a Public-Private Partnership (PPP) procurement option. The procurement option is a sure route through which infrastructural provision can be sustained. This paper reviews literature on PublicPrivate Partnership by buttressing on the expected roles of the government through the Governance theory concept.
\end{abstract}

Keywords: Innovation, Procurement option, PPP, Developing country.

\section{INTRODUCTION}

There has been an assertion that governments across the globe are faced with limitations in meeting the demand for infrastructural supply and management (Babatunde et al. 2015). United Nations (2009) however revealed that one of the key limitations to the supply of infrastructures in developing economies can be attributed to a funding issue. This warranted the Government from the developing countries of the world to solicit for private sector collaboration in infrastructural provisions through the platform of Public-Private Partnership (Ibem 2010).

The Public-Private Partnership (PPP) infrastructure procurement option has been a trending issue of debate across the globe since its adoption (Ojelabi et al. 2017). It has generated mixed reactions from stakeholders as to its adoption as a tool for infrastructure procurement. The controversy surrounding the PPP procurement option was traced to different perceptions of stakeholders on PPP across the globe. Monibot (2010) opined that PPP adoption in infrastructure procurement has enriched some contractors due to the excessive profit made from the execution of public works. Sambrani (2014) also viewed the Public-Private Partnership as a medium through which governments are shifting infrastructure provision responsibility to the private sector. However, Robinson et al. (2010) opined that it is a medium through which sluggishness in the provision of infrastructure facilities by the public sector can be managed. Arewa and 
Farrell (2011) however asserted that PPP has come to stay because infrastructure provision is gradually overwhelming the government.

The multi-dimensional application of PPP has diversified such that it cannot be capped into a single definition. The World Bank Institute (2012) defined PPP as a long-term contractual relationship between private party and government agency towards public asset or service provision. Zhang and Cheng (2013) also referred to Public-Private Partnership as a contractual agreement in which the private sector is responsible for provision and management of public works and services in a long-term for public sector acquisition. For this study, Public-Private Partnership is defined as a synergy between the public sector (government) and the private sector towards infrastructure provision in which the private sector is saddled with the management responsibility while the public sector is to provide the enabling environment.

\section{APPRAISING THE THEORY SUPPORTING PUBLIC-PRIVATE PARTNERSHIP IN INFRASTRUCTURE DELIVERY}

The emergence and acceptance of the Public-Private Partnership (PPP) procurement route in infrastructures delivery are not without a root, it stems out from some the existing theories which include new public management theory and governance theory among others.

One of the theories that give credence to the Public-Private Partnership (PPP) procurement is the new public management theory. Gruening (2001) asserts that the theory is based on the reinvention of government. Osborne and Plastrik (2000) viewed New Public Management as a practical management approach to controlling operational challenges in government. Aucoin (1990) reinforced that reinventing government is only feasible under flexible management and customer's oriented style rooted in private sector operational techniques.

Likewise, the governance theory supports the advent of Public-Private Partnership in the procurement of social and economic infrastructures. Montenegro and Bulgacov (2014) explained that governance and government do not mean the same as the former signifies the change in the latter. Pierre (2000) referred to governance as a system that is capable of sustaining coordination and togetherness among diverse actors with different purpose and objectives. Stoker (1998) make some propositions on governance one of which it refers to governance as the set of institutions drawn from actors beyond the government toward solving social and economic issues.

\section{PUBLIC-PRIVATE PARTNERSHIP PRACTICES ACROSS THE GLOBE}

Public-Private Partnership procurement option is very crucial in infrastructural delivery, as such that developing and developed countries across the globe are engaging in practices that can encourage the attraction of the private investors and as well grantee the procurement acceptance by the people. It is not debatable to state that the developed and developing nations differs in infrastructure strength and financial capacity. These two factors to a larger extent dictate the varying practices between the two regions in Public-Private Partnership from research findings. Winch et al. (2012) revealed that developed countries like United Kingdom, France and Japan immediate demand for infrastructure development is not as high as for countries in the developing world as they have reached maturity level in infrastructure development and public welfare services. The researchers revealed that the available infrastructures in the developed world are aging and likewise the population which is likely to impact on tax revenue in the future and increases social services expenditure in medical and health infrastructures. Despite the visible need for infrastructures development and maintenance, the acceptance of PPP for its procurement among the people is not allowed if they are to pay for the services. As such, the government mostly engaged PPP for social projects that it has the capacity to make a unitary charge to the 
private contractor. Irrespective of the source of financing the PPP projects, value for money appraisal is of uttermost important in the use of PPP in public infrastructures in the developed world.

On the other hand, the need for infrastructures development in the developing world is very high and the financial means of closing the infrastructural gap is not readily available. The countries in this region are mostly dependent on private finance in ensuring equity in their social and economic infrastructure supply. Winch et al. (2012) explained the practice in the use of PPP in the procurement of infrastructures through a case study of some selected countries like Indonesia and India from the developing world. The researchers revealed that the governments of Indonesia and India attract private investors by providing financial assistance to limit the private party risk despite the certainty of the users paying for the facility. This is necessary because the cash flow from the users are not sufficient to augment the initial investment due to the political constraint in the charges to the users. The government support grant is called viability gap fund schemes in India and modified BOT schemes in Indonesia. The for value for money assessment is not practiced in this region due to a heavy commitment of the private investors and primary concern for the use of the procurement option is mainly for infrastructural development.

\section{GOVERNMENT ROLE IN PUBLIC-PRIVATE PARTNERSHIP PROCUREMENT}

PPP sustainability in any country is highly dependent on the parties involved which are mainly the government and the private sector. It is evidenced by PPP's description that it takes two to make PPP functional. However, Namblard (2000), emphasized that the parties (governments and the private sector) are not altogether equal as much premium is placed on one than the other.

Wibowo and Alfen (2015) however, emphasized that the government is inevitable in the implementation of the PPP procurement option. Therefore, the researchers identified government role critical to the development of PPP under some key categories to include; legal, and regulatory provisions, policy framework, public sector capacity, and projects preparation and planning.

The PPP capacity to deliver is dependent on the credible legal and regulatory framework. The legal and regulatory tool is an essential anchor required to keep PPP from drifting from its expectations. Tafesse (2014) further buttressed that the existence of legal and institutional environment is very crucial prior to the adoption of PPP tool. The need for an established legal and regulatory tool in PPP affairs is to ensure that operations of PPP are not totally been dictated to by the government.

Policy development has been the norms for all going-concerns in every area of life. It has been found to be the driving force behind the success and sustainability of business and organization around the world. An organization that lacks policy development is without control. Georghiou et al. (2014) identified the role of policy as a tool used in developing capacity and also aids management of an organization to achieve the expected outcome. It is evidenced by the foregoing that policy development is highly critical to the continuous operation of organizations or businesses. Therefore, the sustainability of Public-Private Partnership (PPP) as a form of business is dependent on sound policy development. Srivastav and Shakaya (2012) opined that trust is one of the fundamental requirements for partnership between the Governments and the private investors to thrive under the platform of PPP and such can only be achieved under a sound policy development.

Public-Private Partnership (PPP) procurement system has been lauded as a sustainable and realistic medium of infrastructural procurement by stakeholders around the globe. The laudable compliment of this procurement option will not have been without the contributions of the parties 
involved. The private and the public sectors have been affirmed to be the bedrock of this procurement system, however, Namblard (2000), asserted that the parties are not on the same pedestal in the discharge of their duties under the procurement system. Irrespective of their varying positions, lack of competency of either of this party can compromise the delivery system. European PPP Expertise Centre (2015) consented that deficiency in skill required for PPP operation can affect the PPP process even under the right framework. It was further stated that the weakness of public sector capacity has been one of the challenges contributing to the failure of the PPP system. Public sector capacity is very crucial to the success of PPP as it dictates the knowledge base and ability of the participants. The foregoing fact has warrants the need to address the human capacity of the public party being one of the key players under the procurements option.

Preparation and planning are the inseparable twins that are crucial to the success of any proposed project. Rui et al. (2015) affirmed that preparation and planning are highly essential in managing time delay, cost overrun and quality defects that plague most construction projects. Preparation and planning are drivers of projects successful delivery and are not limited to a procurement option. It encompasses all procurement routes including PPP that is used for the delivery of social and economic projects. Inwa et al. (2014) also consented to the need to develop a workable plan for procurements of construction projects due to its uniqueness in terms of complexity compared to other forms of general procurements. Among other forms of construction projects procurements delivery route, PPP has been found to be more demanding in term of management. The need for management of PPP procurement option can be hinged on the complexity of the system as a result of the parties involved and the construction process. World Economic Forum (2016) further linked the complexity of PPP procurements option to the large team and multiple stakeholders which include ministries, banks, investors, construction firms, regulators and users among others that are crucial to the operation of this procurement option. However, management of these multiple stakeholders for effective delivery of PPP projects cannot be achieved without proper preparation and planning of the procurement option. Therefore, proper planning of PPP projects are dependent on some key determinants as revealed by World Economic Forum (2016) and it includes thorough project preparation process, bankable feasibility study, balanced risk allocation, and regulation and ensuring a conducive enabling environment is guaranteed, among others.

\section{CONCLUSIONS}

This paper reviewed the government role in the implementation of PPP procurement in the delivery of social and economic infrastructures. The findings from the study revealed that the practices in the implementation of PPP in the developed and developing countries differ. Governments from the developed world only embark on PPP projects that have the capacity to finance due to their maturity in infrastructural strength and the resistance of the people to pay for tariffs. On the other hand, governments in the developing countries pushing for PPP implementation are very many; however, private investors are very careful to invest in the regions due to the need for the certainty of social and economic infrastructure, the risk in doing business in the regions and the uncertainty of governments. The study, therefore, revealed that the attraction of the private investors to engage in PPP is dependent on the roles of the governments, which include managing the inherent risk, encouraging private investor, enhancing public sector capacity in PPP, establishing sound legal and regulatory framework for PPPs, developing sound policies to promoting PPP and ensuring adequate preparation and planning. 


\section{Acknowledgments}

The researchers appreciate the publication support fund given by Covenant University towards the publication of this article.

\section{References}

Arewa, A., and Farrell P., The Private Finance Initiative: Why Value for Money Remain Elusive, CIB.TG72/ARCOM Doctoral research workshop, University of Central Lancashire, United Kingdom, 2011.

Aucoin, P., Administrative Reform in Public Management: Paradigms, Principles, Paradoxes and Pendulums. Governance, International Journal of Policy and Administration, 3, 115-137, 1990.

Babatunde, S. O., Perera, S., Zhou, L., and Udeaja, C., Barriers to Public Private Partnership projects in Developing Countries: A Case of Nigeria, Engineering, Construction and Architectural Management, 22(6), 669-691, 2015.

European PPP Expertise Centre, PPP Motivations and Challenges for the Public Sector, 2015. Retrieved from www.eib.org/epec/resources/publications/epec_PPP_motivations_and_challenges_en in July, 2018.

Georghiou, L., Elder J., Uyarra, E and Yeow J., Policy Instruments for Public Procurement of Innovation: Choice, Design and Assessment, Technological Forecasting and Social Change, 86, 1-12, 2014.

Gruening, G., Origin and Theoretical Basis of New Public Management, International Public Management Journal, 4(1), 1-25, 2001.

Monibot, G., The UK'S Odious Debts: Many PFI Deals Are Undemocratic, It's Time We Stop Honoring Them, 2010. Retrieved from http://www.monbiot.com/2010/11/22/the-uks-odious-debts/ in July, 2018.

Montenegro, L. M., and Bulgacov, S., Reflections on Actor-Network Theory, Governance Networks, and Strategic Outcomes, BAR-Brazilian Administration Review, 11(1), 107-124, 2014.

Namblard, C., In Favour of Pragmatic Approach Towards Public-Private Partnership, In Perrot, J.Y and Chatelus G. Financing of Major Infrastructure and Public Service Projects: Public Private Partnership, Presses Points, 2000.

Ibem, E., An Assessment of the Role of Government Agencies in Public-Private Partnerships in Housing Delivery in Nigeria, Journal of Construction in Developing Countries, 15(2), 23-48, 2010.

Inwa, I. I., Gthae, W., and Stephen, D., Application of Project Planning Techniques in Construction Procurement: The Case of Nigerian Indigenous Contractors, International Journal of Economic Research and Investment, 5(1), 31-47, 2014.

Ojelabi, R. A., Oyeyipo, O., and Afolabi, A. O., Built Environment Professionals' Perception of the Effectiveness of Building Control Measures in Lagos State, Journal of Construction In Developing Countries, 22(1), 41-54, 2017.

Osborne, D, and Plastrik, P., The Reinventors Field Book: Tools for Transforming Your Government, San Francisco, CA, 2000.

Pierre, J., Introduction: Understanding Governance in Debating Governance. Authority Steering and Democracy, Oxford University Press, 1-12, 2000.

Robinson, H., Carrillo, P., Anumba, C. J., and Patel, M., Governance \& Knowledge Management for Public-Private Partnerships, Wiley-Blackwell, Oxford, 2010.

Rui, L. M., Ismail, S., and Hussaini, M., Professional Development of Project Management for Contractor in The Construction Project. A Review, Procedia-Social and Behavioral Sciences, 174, 2940-2945, 2015.

Sambrani, V. N., PPP for Asia and African Perspective Towards Infrastructure Development: A Case Study of Greenfield Bangalore International Airport, India, Social and Behavioral Sciences, 157, 285295, 2014.

Srivastav, H., and Shakya, P. L., Policy Framework for Public-Private Partnership (PPP) Projects in Nepal, $3^{\text {rd }}$ Ministerial Meeting on PPP for Infrastructure Development, Tehran, Iran, May 11-14, 2012.

Stoker, G., Governance as Theory: Five Prepositions. International Social Science Journal, 50(55), 17-28, 1998.

Tafesse, T., Public-Private Partnership in Development: Lesson in Devising Legal and Institutional Framework from South Korea, Public Policy and Administration Research, 3(4)50-57, 2014. 
United Nations, What is Good Governance? 2009. Retrieved from www. gdrc.org/ugov/escap.governance.html in June 2018.

Wibowo, A and Alfen, H. W. Government-Led Critical Success Factors in PPP Infrastructure Development, Built Environment Project and Asset Management, 5(1) 121-134, 2015.

Winch, G.M., Onishi, M., and Schmidt, S., Taking Stock of PPP and PFI Around the World, Certified Accountant Education Trust, London, 2012.

World Bank Institute, Public-Private Partnerships, Reference Guide Version 1.0. International for Reconstruction and Development Association, Washington D.C, USA, 2012.

World Economic Forum. The Global Competitiveness Report, 2016-2017, 2016. Retrieved from www.weforum.org/gcr in August 2018.

Zhang, X., and Cheng S. A Systematic Framework for Infrastructure Development Through Public-Private Partnerships, International Association of Traffic and Safety Sciences (IATSS) Research, 36, 88-97, 2013. 